\title{
The Father's Subjective Behavior in Ancient Rome Education and Its Enlightenment
}

\author{
Wang Youming \\ School of Management and communication in Capital University of Physical Education and Sports, Beijing , \\ China
}

Keywords: Ancient Roman period; father; teacher; family education

\begin{abstract}
Education is the means to the purpose. During the period of the Roman Republic, in the family life and social culture, the father's responsibility was not only to teach the children the knowledge they need in daily life, but also to assume the authority of the ancient Roman parents teachers, priests. Through the study of the father's role in demonstrating his children's speech and action, this paper explores the father's main responsibility and educational mode in the early family education in ancient Rome. The literature search method was used to sort out and analyze the duties and roles of fathers raising children in family education in ancient Rome. The induction and generalization of the materials in the study were emphasized, and the "text" elaboration was emphasized: The study attempts to clarify the basic situation of father's physical and psychological training for children from the perspective of law and reflect the role and significance of ancient Roman family education on the early education in China. In the discussion, different research methods will be adopted depending on specific responsibilities, including impact studies, acceptance theory, and so on. The father's words and deeds have an important influence on the growth and education of children and on the prosperity and development of ancient Rome. The father's authority in family education in ancient Rome strengthened children's cognition of tradition and ancestors, thus reflecting on the problems and countermeasures of the weakening of father's role in current family education.
\end{abstract}

\section{Introduction}

Since ancient times, mothers have played an important role in the family education of their children, especially in ancient feudal society. However, ancient Rome is the opposite. They believe that father is a symbol of strength. They regard strong personality, rights and etiquette as criterion, and believe they have supreme rights and responsibilities for the education of children. When the Western educational academy studied ancient Roman education, the father's responsibility in the family was an unavoidable problem. Based on the father's responsibility in family education and his relationship with children, this paper analyzes the ancient Roman family education and examines the weakening of father status in family education in China.

Through the analysis of the social and cultural characteristics of ancient Rome, it is found that the father's responsibility in the ancient Roman family education is mainly manifested in three aspects: The law strengthens the responsibility of the ancient Roman father in moral exhortation. Fathers' words and deeds teach life skills and cultural knowledge. The authority of the father reinforces the sense of awe of tradition and ancestors.

\section{The law strengthens the role of fathers in the family during Roman times}

Ancient Rome was first a small city-state with slavery. Through continuous conquest and expansion, it became a great empire across Europe, Asia and Africa. The famous German jurist 
Rudolf von Jhering pointed out in his book "The Spirit of Roman Law": "The Roman Empire had conquered the world three times, with force for the first time, religion for the second time, and law for the third time. The extermination of force was ruined by the demise of the Roman Empire. Religion narrowed the influence with the improvement of people's ideological consciousness and the development of science. Only the law conquered the world is the most enduring conquest[1].” In the political system of ancient Rome, law played an important role. Based on the law, the exchange of economic and cultural in various regions will be carried out in a broader scope. Similarly, family life and education in ancient Rome also follow the law. The "lex duodecim tabularum" of Rome stipulates that citizens enjoy multiple rights, namely summoning, trial, inheritance, private, religious, etc. Among them, the father's right stipulates: the father's rights to the children; the husband's rights to the wife; the master's rights to the slaves. The extent to which these rights are used is rarely known or controversial. But in the social life of ancient Rome, everything was family-centered, especially around the father's responsibilities and rights. This is the most characteristic and important right -- patriarchy. Gaius thinks: It is impossible for any nationalities to dominate their children greater than Roman citizens[2].

\subsection{Father's management rights and obligations}

The patriarchal power is supreme in the family and has the right to decide everything. It is the most distinctive right in family education. According to ancient Roman law, for children with disabilities, the father has the right to decide his life and death, and to control the child's right to kill and use, and to restrict the rights of the child by law. For an adult son, even if he holds a national high-ranking public office and becomes a warrior or government official with power, the father's rights still exist. De Noni Lucius wrote in "the history of Rome": "The legislator of ancient Rome gave the fathers absolute power to his son, a lifelong and effective right. The father had the right to imprison and whipping his son, the right to treat his son as a prisoner, and even the right to kill his son.” For the daughter, the father also has the right to transfer his rights to another family through religious means, even if the daughter is married, he will not lose his rights. At the same time, the father has an unshirkable right and obligation to the national politics, economy, religion and education.

\subsection{Father's moral cultivation and obligation to children}

In early family education, ancient Roman chiefs, priests, and children of the free class wore purple-red robes (praetexta) before the age of 16 to distinguish them from adults. They are strictly taught by their father until 16 or 17 years old[3]. When becoming a formal citizen of Rome, they need to wear an adult robe(toga virilis). Toga virilis is a robe worn by a Roman child in adulthood, it is usually white[4]. Pliny said:"The father of each child is his schoolmaster". Beside his father, he must learn from his father the traditional life of Rome, follow his father to visit famous people and ask to learn "political oratory and statecraft. These skills are not available to a limited family circle." To accompany his father to a friend's house, to serve the elders, etc.; To participate in various social activities with his father, such as listening to lectures or public debates at the Roman Forum or the Presbyterian Church. The main purpose is to form a spirit of loyalty and filial piety by imitating the behaviors of the upper class. Cicero said:"My father took me to Scaevola and asked me to never leave him as much as possible". Participating in social activities and learn social etiquette from an early age. This apprenticeship is called the "square apprenticeship"; Those who intend to enter the military life also need to take the initiative to serve the apprenticeship. Even if they become adults, they become citizens and their private lives are subject to their father. Roman law stipulates that only the death of his father ends his rights and obligations. In family education, 
the father is the parent, the priest. The emphasis on moral training allows children to know how to be grateful to their parents and understand their duties as citizens - to serve the country.

\section{Words and deeds laid the father's position in family education}

\subsection{Cultivation of survival skills}

In the ancient Roman family life, when the child's childhood was over, his father took over his education and formed a father-son companionship relationship. Usually, the father teaches children various survival skills in their daily lives and takes them to the field to work. In labor, they learn the knowledge of land measurement and calculation. "Throughout the youth, they spent the hard, frugal and diligent life, and opened the barren hills of Sabin until the planting harvest". The old Cartew so described. There was no school education in early Rome, and family education was particularly important. The father is a symbol of authority, and his words and deeds and his accumulated knowledge deeply influence the next generation. Little Pliny's explanation of education is easy to understand:" For our ancestors, education is both an eye thing and an ear thing. Through the observation of the elders, young people learn what they are going to do soon, and know what they should do when they educate their next generations. Everyone takes his father as a teacher." " Sit at the gate and learn from what you see and hear."

\subsection{Physical and mental training}

As the head of the family, the father, in addition to teaching children the survival skills, must also cultivate the child's body and mind. In 1762, Rousseau described sports in "Ai Mier" as: Physical training and mental training. Not surprisingly, in addition to learning survival skills from fathers, physical training has become part of ancient Roman children's daily education. The father should teach children running, boxing, wrestling, hunting, swimming, etc. Marcus Terentius Varro ${ }^{1}$ described her exercise as: The horse riding has no saddle... all kinds of hardships are to exercise the child's physique. With a strong body, it is possible to fight for good and fight for the country on the battlefield.In the twentieth section of "the old Cartew ", Plutarch made a careful description: "Cartew personally served as a child's teacher, teaching his son the Roman law, to throw a discus, to wear a helmet and ride a helmet to fight, and teaching him to punch, to withstand the heat and summer exercise, to chase the waves in the river. Cartew also personally wrote a history book in large letters to familiarize his son with the past of his country..... Cartew took great efforts to cultivate the virtues of his son, just like polishing an outstanding work". In addition, the father also uses epic, folk songs and other literacy training for children. At the dinner table, sing the ballads of early Rome literature with children of the same age. Cicero once said that when children were older, they were required to recite the "lex duodecim tabularum", to remember their obligations as citizens, and to train them in memory and expression.

\section{Father's authority reinforces the respect of tradition and ancestors}

A traditional religious ritual of a nation can give children an inspiring thought. Through solemn ceremonies and the inheritance of fathers, children can understand the history of the nation. At the beginning of the ancient Rome, influenced by much religious consciousness, people's respect for tradition and family deeply made them feel the greatness of the educational concept of Rome. Every morning the child goes to worship the goddess of Vista ${ }^{2}$. Its main purpose is to establish a respect 
from childhood. Every boy and girl has religious devotion and loyalty while strengthening respect for ancestors and traditions. According to ethnic customs, in the funeral of Roman citizens, "the statues of the ancestors of the family should be lined up in the plaza solemnly, and decorated them with badges according to their respective levels. After the parade, read the eulogy, praise the virtues and achievements of the deceased and the glory of the ancestors". In a major event or festival, the child acts as an assistant to the father and assists in everything. "Looking at the statues of these famous people, they stand in line and live like life. Who can not be moved? Is there anything more spectacular than this? The most important thing is that young people are inspired to undertake all forms of hardship for the common good, hoping to win the glory that warriors deserve". In religious festivals, children feel the courage and hardship of their ancestors, gradually forming a sense of awe and their obligations as citizens.

\section{Reflection and revelation}

The authority of the father in Roman family education was adapted to the history of the time, which made the ancient Romans grow from a small country and produced educators like Cicero and Marcus Fabius Quintilianus, which had a great impact on the world cultural pattern. In order to make children develop better and healthier in family education, it is necessary to actively explore the family education model of the nation. How to improve the father's authority in family education from the educational concept and balance the relationship with school education. For a long time, the role of father in family education is in a weak position. The 2015 "China Family Development Report" shows: $28 \%$ of the fathers believe in the concept of education that "fathers bring their children". $15 \%$ of fathers choose to "take time and play games for children". $45 \%$ of fathers' recognition of educational methods is "mother discipline". 12\% the father thought "let go of his own way". The results of this survey show that fathers are influenced by traditional concepts in family education, with fathers outside and mothers inside. Mother affects the child with tenderness. Father has great limitations in the education of children. In the early family education of ancient Rome, mother was in the custody of infancy. At the end of childhood, the father takes over, becoming the leader and instructor of the child, taking on the task of mental and physical training, balancing the role of parents in family education. At present, China is in a period of economic and social transformation. While emphasizing school education, we cannot ignore the role of fathers in family education. The education of father and mother plays different roles at different nodes of the child's growth. Balancing the relationship between the two and the child is more conducive to adjusting the relationship between school education and family education, so as to develop corresponding educational measures and strategies.

First, how to improve the initiative and autonomy of the father in family education from the psychology.

The growth of a child requires the participation of the mother and the involvement of the father. In the ancient Roman family education, the father will personally lead the children to participate in the field work and visit friends. Through the real movement to help children develop social awareness, lead him or her into the real world. This fully reflects that the father is both a friend and a trusted teacher. The initiative and autonomy of father participation in family education in China is relatively lacking. In order to achieve the purpose of active participation, relevant departments in social education make psychological propaganda.Children who lack paternal love are apt to suffer from "lack of fatherly syndrome". The performance is: slow development of skills, intense emotions, poor self-control ability, lack of security and so on. The study found: The smaller the child, the greater the risk. Usually boys are 1-3 times greater than girls. American marital expert Douglas 
analysis: Compared with children who are cared for by their fathers, children who lack fatherly love are easy to drop out of school, and the crime rate is higher in adulthood, which is 2 times higher on average; Girls are more likely to become single mothers when they grow up, with an average of 3 times. Psychological intervention is helpful to improve the initiative and autonomy of fathers in family education.

Second, how to strengthen the role of father from the goal of family education.

With the continuous development of society, policies have been formulated to benefit school education and family education, but there are still many problems, especially education. The root cause of this phenomenon is related to the uncertainty of the educational goals. The twentieth section of " The Old Kathu" records: Kathu made great efforts to cultivate the virtues of his son, just like polishing an excellent work. But Kathu found that his son was docile and kind, but his body was delicate. Despite his lack of physical fitness, the son of Kathu still proved himself to be a real man on the battlefield. Whether this standard is good or bad, but Kathu's cultivation of children's morality, the traditional guardianship, is admirable. A specific and operational goal is the guarantee of progress and success in family education. Establishing the balance between maternal love and fatherly love in the family undoubtedly plays a role in promoting school education and social education. In family education, the role of the mother is great.In her warm atmosphere, injecting the strength of father. The father's words and deeds play a great role in shaping the child's character. Fathers can subtly strengthen their children with their strong, hard-working, kind, and respectful enthusiasm. Making them more cultivated and graceful in the cultivation of personality, stimulate children's enthusiasm for society and loyalty for faith, and truly inherit the moral culture.

\section{References}

[1]Bu Fang. The influence of Rome law on Chinese law[J].Forward Position. 2013(21):68-72

[2]Gaius.Institutions[M].Tianjing:Tianjin people's Publishing House,2009

[3]Marquardt,I, p.123-134

[4] Xie Da-ren. Dictionarium Latino-Sinicum[M].Beijing: The Commercial Press,1988 